\title{
A Research Paper on- "Impact of Covid 19 Pandemic on Hospitality Industry with Special Reference to Internship Programme"
}

\author{
Mrs. Priya Bansal (MBA) ${ }^{1}$, Mrs. Swati Agrawal (MBA) ${ }^{2}$ \\ Sr. Faculty@ADYPU, Pune ${ }^{1}$ \\ Pursuing PHD from Sabarmati Uni. Ahd ${ }^{2}$
}

\section{INTRODUCTION}

Due to the Covid-19 pandemic, the world's economy was shut down almost overnight (UNWTO, 2020). The pandemic has confronted the hospitality industry with an unprecedented challenge. The coronavirus, which surfaced in a Chinese seafood and poultry market in December 2019, has spread to nearly every country, upending life and derailing the global economy. The virus has killed more than 1.6 million and sickened more than 76 million over the last year. The World Health Organization has declared the situation a global pandemic. Critical global responses to control the spreading of the COVID-19 pandemic have included travel restrictions, shelter-in-place and social distancing orders.

Most countries around the world have imposed partial or complete border closures, with travel bans affecting the majority of the world's population. With millions suddenly unemployed, uncertainty over economic recovery, and global fears of continuing COVID-19 spread and its future waves, the hospitality industry was among the first industries affected, and it will be among the last industries to recover.

This study reports on a systematic review of the published literature used to reveal the current research investigating the hospitality industry in the face of the COVID-19 pandemic.

\section{OBJECTIVES OF THE STUDY}

1. To study the challenges faced by the hospitality industry.

2. To understand the role of hospitality industry in this pandemic situation.

3. To study the importance of hospitality industry for the people during this covid-19 pandemic.

4. To study the impact of covid-19 pandemic on hospitality industry employees.

5. To measure the impact of covid-19 in the term of economies.

\section{PROBLEM STATEMENT}

Real world has unexpected situations which cannot be simulated in classrooms. There are some ways for university students to experiences whatever they have learned in classrooms as interns, and it has seen that they have positive impact on development of the hospitality industry by learning and applying their knowledge to the industry (Simmons, 2006). An appropriate education program with an international standard should be provided and changed to fulfill the scientific and professional needs of students, and more, to meet the needs of hospitality and tourism industry. Furthermore, because of fast changes in this industry, the programs should have some specifications to give abilities and skills to graduate to add values to active organization in the industry (Kazazi \& Marashi,2003). Internship could be introduced as the combination of theoretical learned and practical work experience which helps graduated and new employees to deal real work and be familiar with something that they have never learned in any classes (Beggs, Ross \& Goodwin, 2008).

There is an emphasis on hospitality students to have experiential and hands-on learning experience to meet the demand of the industry, so they may get benefits from their internship program (Zopiatis, 2007). 
International Advanced Research Journal in Science, Engineering and Technology

Vol. 8, Issue 5, May 2021

DOI: $10.17148 / I A R J S E T .2021 .8585$

\section{LITERATURE REVIEW}

\begin{tabular}{|c|c|c|c|c|}
\hline Factor & $\begin{array}{l}\text { Research } \\
\text { Elements }\end{array}$ & Research or book title & Author (s) & Year \\
\hline & Knowledge & $\begin{array}{l}\text { Human resource management in the } \\
\text { hospitality industry }\end{array}$ & Hayes \& Ninemeier & 2009 \\
\hline \multirow[t]{7}{*}{$\begin{array}{l}\text { Intern’s } \\
\text { quality }\end{array}$} & Expectations & $\begin{array}{c}\text { Over qualified and } \\
\text { under experienced : } \\
\text { Turning Graduates intohospitality managers }\end{array}$ & $\begin{array}{l}\text { Raybould, Mike, } \\
\text { Wilkins, Hugh }\end{array}$ & 2005 \\
\hline & & $\begin{array}{l}\text { Hospitality Internships : } \\
\text { An industry View }\end{array}$ & $\begin{array}{l}\text { Downev, James F, } \\
\text { DeVeau Linsley R }\end{array}$ & 1988 \\
\hline & $\begin{array}{c}\text { Expectations/perce } \\
\text { ption/skills }\end{array}$ & $\begin{array}{l}\text { Interns perception of internships: } \\
\text { A look at work ,supervision and appraisals }\end{array}$ & T.C Girard & 1999 \\
\hline & Perceptions & $\begin{array}{c}\text { Over qualified and under experienced: } \\
\text { Turning graduates into hospitality managers }\end{array}$ & $\begin{array}{l}\text { Raybould, Mike, } \\
\text { Wilkins, Hugh }\end{array}$ & 2005 \\
\hline & Skills & $\begin{array}{c}\text { Hospitality Internships : An industry View } \\
\text { in Cyrus: A genuine academic experience or } \\
\text { a continuing frustration }\end{array}$ & $\begin{array}{l}\text { Downev, James F, } \\
\text { DeVeau, Linsley R }\end{array}$ & 1988 \\
\hline & $\begin{array}{l}\text { Skills/Abilities/ } \\
\text { Responsibility }\end{array}$ & $\begin{array}{c}\text { A comparison of students and practitioner: } \\
\text { Perspectives of the travel and tourism } \\
\text { internships }\end{array}$ & $\begin{array}{l}\text { Beggs B, Ross C, } \\
\text { Goodwin B. }\end{array}$ & 2008 \\
\hline & & $\begin{array}{l}\text { Interns perception of internships: A look at } \\
\text { work, supervision and appraisals }\end{array}$ & T.C Girard & 1999 \\
\hline \multirow{6}{*}{$\begin{array}{l}\text { Designed } \\
\text { Academic } \\
\text { program }\end{array}$} & Introduction & $\begin{array}{c}\text { Industry internships : feedbacks from } \\
\text { participating faculty and industry executives }\end{array}$ & $\begin{array}{l}\text { Harris, Kimberly J, } \\
\text { Zhao, Jinlin }\end{array}$ & 2004 \\
\hline & $\begin{array}{c}\text { Report } \\
\text { presentation/Indust } \\
\text { ry adjustment }\end{array}$ & Hospitality Internships : An industry View & $\begin{array}{l}\text { Downev, James F, } \\
\text { DeVeau, Linsley R }\end{array}$ & 1988 \\
\hline & Supervision & $\begin{array}{l}\text { Interns perception of internships: A look at } \\
\text { work, supervision and appraisals }\end{array}$ & T.C Girard & 1999 \\
\hline & Assessment & $\begin{array}{c}\text { Hospitality internships in Cyprus : a genuine } \\
\text { academic experience or a continuing } \\
\text { Frustration? }\end{array}$ & Anastasios Zopiatis & 2007 \\
\hline & $\begin{array}{l}\text { Industry } \\
\text { adjustment }\end{array}$ & $\begin{array}{c}\text { Over qualified and under experienced : } \\
\text { Turning Graduates into } \\
\text { hospitality managers }\end{array}$ & $\begin{array}{l}\text { Raybould, Mike, } \\
\text { Wilkins, Hugh }\end{array}$ & 2005 \\
\hline & Program Length & $\begin{array}{c}\text { Industry internships : feedbacks from } \\
\text { participating faculty } \\
\text { and industry executives }\end{array}$ & $\begin{array}{l}\text { Harris, Kimberly J, } \\
\text { Zhao, Jinlin }\end{array}$ & 2004 \\
\hline $\begin{array}{l}\text { Hotel program } \\
\text { handling }\end{array}$ & Orientation & $\begin{array}{c}\text { Industry internships : feedbacks from } \\
\text { participating faculty and industry executives }\end{array}$ & $\begin{array}{l}\text { Harris, Kimberly J, } \\
\text { Zhao, Jinlin }\end{array}$ & 2004 \\
\hline
\end{tabular}




\section{International Advanced Research Journal in Science, Engineering and Technology}

Vol. 8, Issue 5, May 2021

DOI: $10.17148 /$ IARJSET.2021.8585

\begin{tabular}{|c|c|c|c|c|}
\hline & $\begin{array}{c}\text { Environment/plann } \\
\text { ed } \\
\text { program/Assigned } \\
\text { tasks, duties } \\
\text { hands on jobs }\end{array}$ & $\begin{array}{l}\text { Hospitality internships in Cyprus : a genuine } \\
\text { academic experience or a continuing } \\
\text { frustration? }\end{array}$ & Anastasios Zopiatis & 2007 \\
\hline & & $\begin{array}{c}\text { Industry internships : feedbacks from } \\
\text { participating faculty } \\
\text { and industry executives }\end{array}$ & $\begin{array}{l}\text { Harris, Kimberly J, } \\
\text { Zhao, Jinlin }\end{array}$ & 2004 \\
\hline & & $\begin{array}{l}\text { Interns perception of internships: A look at } \\
\text { work, supervision and appraisals }\end{array}$ & T.C Girard & 1999 \\
\hline & Mentoring & $\begin{array}{c}\text { Over qualified and under experienced : } \\
\text { Turning Graduates into } \\
\text { hospitality managers }\end{array}$ & $\begin{array}{l}\text { Raybould, Mike, } \\
\text { Wilkins, Hugh }\end{array}$ & 2005 \\
\hline & & $\begin{array}{c}\text { Industry internships : feedbacks from } \\
\text { participating faculty } \\
\text { and industry executives }\end{array}$ & $\begin{array}{l}\text { Harris, Kimberly J, } \\
\text { Zhao, Jinlin }\end{array}$ & 2004 \\
\hline & & $\begin{array}{c}\text { Interns perception of internships: A look at } \\
\text { work, supervision and appraisals }\end{array}$ & T.C Girard & 1999 \\
\hline & $\begin{array}{l}\text { Incentives, } \\
\text { rewards, hiring } \\
\text { opportunities }\end{array}$ & $\begin{array}{c}\text { Industry internships : feedbacks from } \\
\text { 485articipating faculty } \\
\text { and industry executives }\end{array}$ & $\begin{array}{l}\text { Harris, Kimberly J, } \\
\text { Zhao, Jinlin }\end{array}$ & 2004 \\
\hline & & $\begin{array}{c}\text { Interns perception of internships: A look at } \\
\text { work, supervision and appraisals }\end{array}$ & T.C Girard & 1999 \\
\hline & & $\begin{array}{c}\text { A comparison of students and practitioner: } \\
\text { perspectives of the travel and tourism } \\
\text { internships }\end{array}$ & $\begin{array}{l}\text { Beggs B, Ross C, } \\
\text { Goodwin B. }\end{array}$ & 2008 \\
\hline \multirow[t]{2}{*}{ Feedback } & Interns & $\begin{array}{c}\text { Industry internships : feedbacks from } \\
\text { participating faculty and industry executives }\end{array}$ & $\begin{array}{l}\text { Harris, Kimberly J, } \\
\text { Zhao, Jinlin }\end{array}$ & 2004 \\
\hline & Academy & $\begin{array}{c}\text { Industry internships : feedbacks from } \\
\text { 485articipating faculty } \\
\text { and industry executives }\end{array}$ & $\begin{array}{l}\text { Harris, Kimberly J, } \\
\text { Zhao, Jinlin }\end{array}$ & 2004 \\
\hline
\end{tabular}

\section{METHODOLOGY / ANALYTICAL PROCEDURES}

A descriptive survey design has been employed for this research;the aim of applied research is to develop applied knowledge in a specificfield (Sarmad et al, 2000). Data is collected through Questionnaire.

\section{POPULATION AND SAMPLING}

We selected the peoples, staff, students and academics who are doing internship in any hotel who are to get the survey done. Based on the literature the researchers have tried to choose a variety of involved people as stakeholders in the hospitality industry (Raybould \&Wilkins, 2005).

\section{ANALYSIS AND INTEPRETATION:}

The analysis is done based on the descriptive statistics for demographic factors and others factors affecting the quality of interns in the hotel industry.

\section{RESPONSES OF DEMOGRAPHIC ANALYSIS}

- $\quad$ From the 25 respondents, $58 \%$ were outsiders and $42 \%$ were students. 


\section{International Advanced Research Journal in Science, Engineering and Technology}

Vol. 8, Issue 5, May 2021

DOI: $10.17148 /$ IARJSET.2021.8585

\subsection{Age}

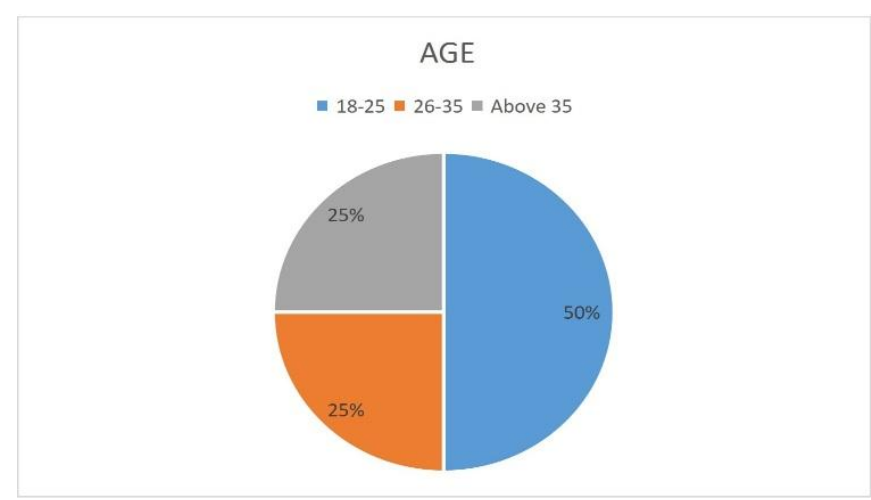

\subsection{Level of education}

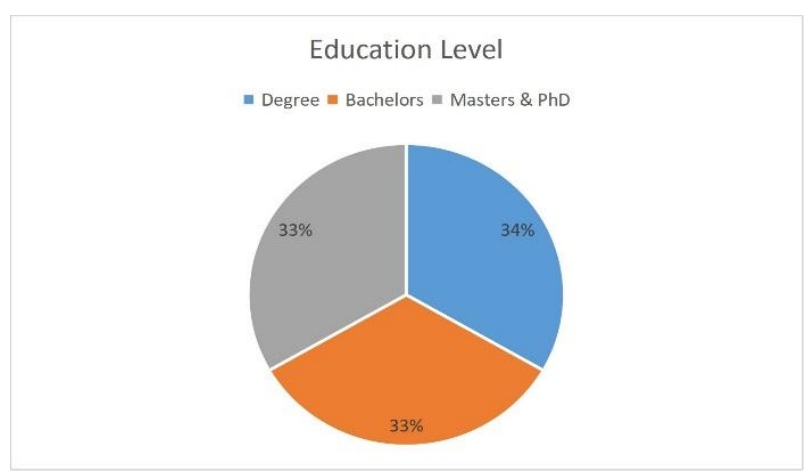

1.3

Participation of interns:

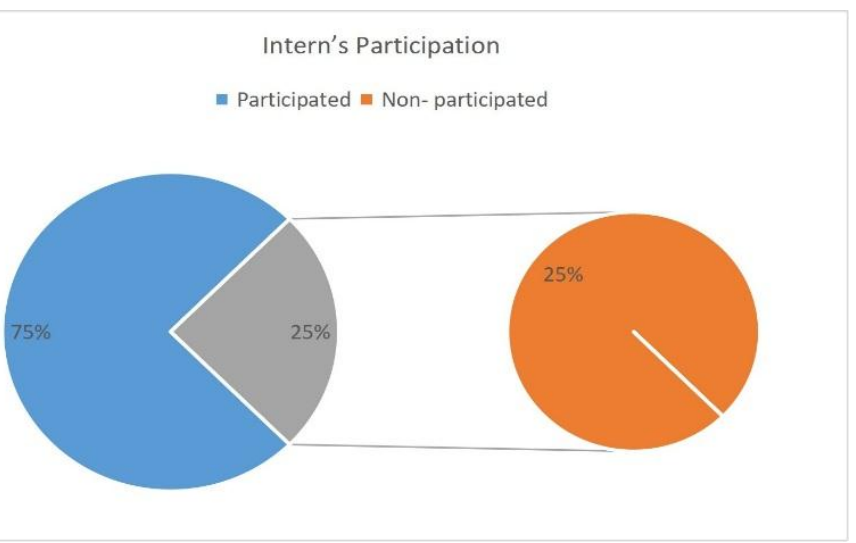

\subsection{ELEMENTS OF INTERN'S QUALITY}

1 Hypothesis 1: Intern's quality is important during internship. Knowledge, expectations, perceptions, skills, abilities and work responsibility are few elements in this factor. These item are analyzed from the point of view of students and outsiders.Following graphs represents the data in table 1.1. In this outsiders includes hotel staff, traveller \& employees.

TABLE 1.1 ELEMENTS (Quality of interns)

\begin{tabular}{|c|c|c|c|}
\hline Elements & Outsiders & Students & Mean \\
\hline Knowledge & 3.53 & 3.61 & 3.57 \\
\hline Expectations & 4.18 & 4 & 4.09 \\
\hline Perceptions & 4.18 & 3 & 3.59 \\
\hline Skills & 3.19 & 3.7 & 3.445 \\
\hline Ability & 3.82 & 3.65 & 3.735 \\
\hline Responsibility & 4.07 & 4.1 & 4.085 \\
\hline
\end{tabular}




\section{International Advanced Research Journal in Science, Engineering and Technology}

Vol. 8, Issue 5, May 2021

DOI: $10.17148 /$ IARJSET.2021.8585

The most important factor that affect the intern's quality is Expectation and Perceptions to tell interns to believethat responsibility is the most influencing element. The entire views is shown in following graph:

\section{Graph 1.5}

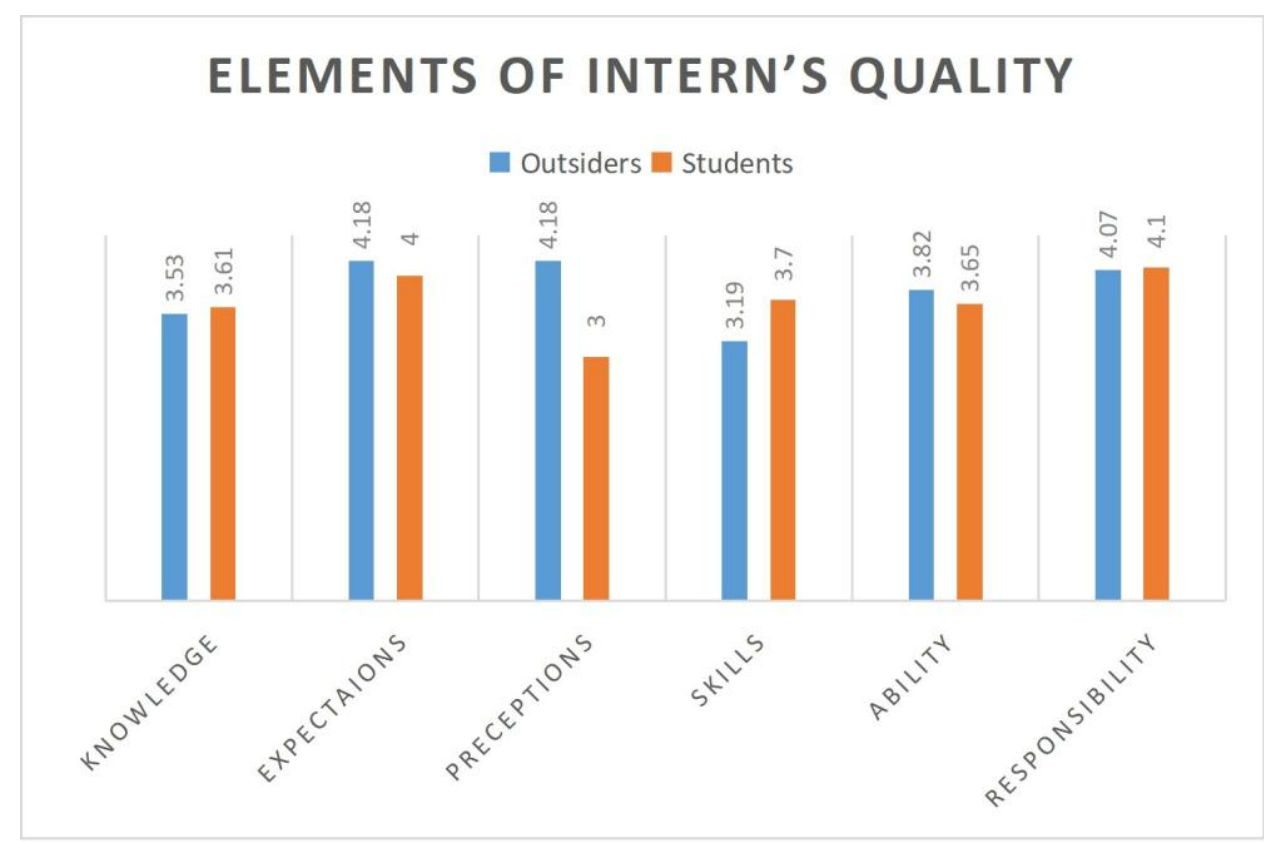

In the above graph as shown outsiders response for expectations and perception is more than the students response. The total of mean is 22.5.As in the graph the elements of intern's quality is combined and shown. The mean findings on the responses, the element shows the overall importance in following graph

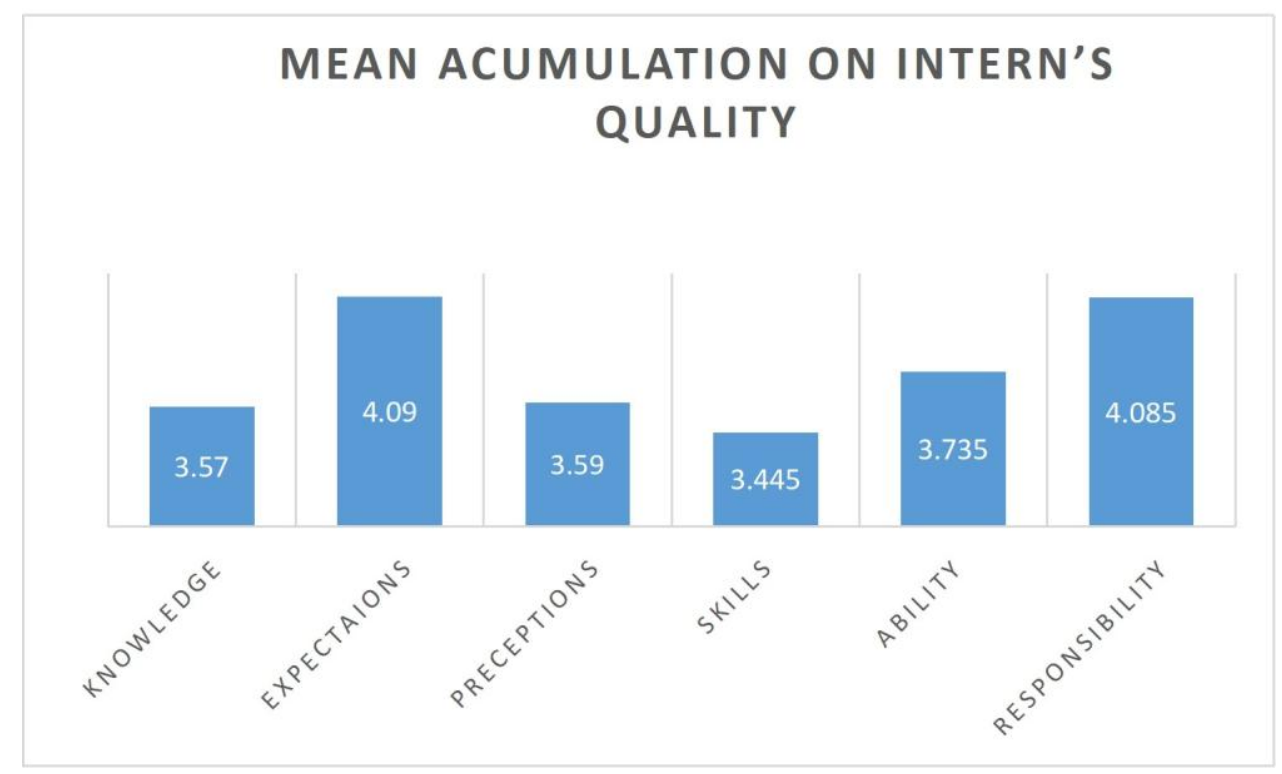

Hypothesis 2: It is the another factor of which plays the significant rolein the internship. The elements in this factor are Introduction, report presentation, supervision, assessment, industry adjustment and program length it effects the internship directly. The analysis is shown in the tabular and the graphical form as follows: 
International Advanced Research Journal in Science, Engineering and Technology

Vol. 8, Issue 5, May 2021

DOI: $10.17148 / I A R J S E T .2021 .8585$

TABLE 4.2 ELEMENTS

\begin{tabular}{|l|c|c|c|}
\hline Elements & Outsiders & Students & Mean \\
\hline Introduction & 2.23 & 4 & 3.115 \\
\hline Report presentation & 3 & 4.15 & 3.575 \\
\hline Supervision & 4 & 3.64 & 3.82 \\
\hline Assessment & 3.15 & 3 & 3.075 \\
\hline Industry Adjustment & 4 & 3.89 & 3.945 \\
\hline Program length & 3.42 & 3.25 & 3.335 \\
\hline
\end{tabular}

Graph 1.6

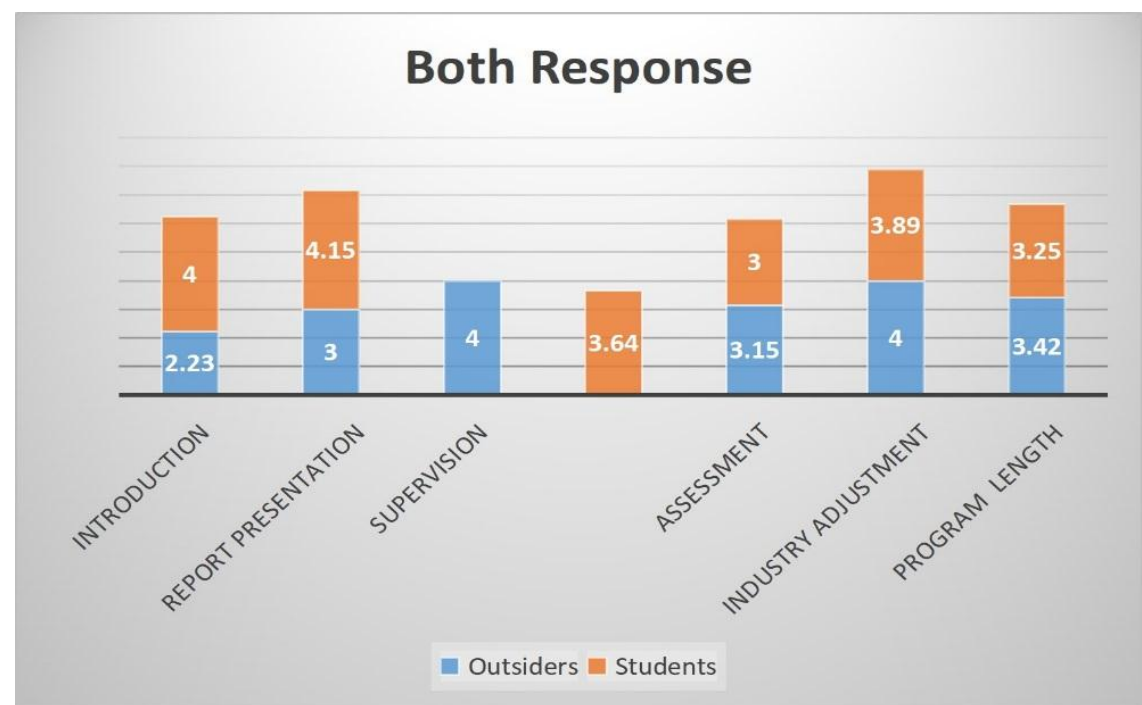

Graph 1.7

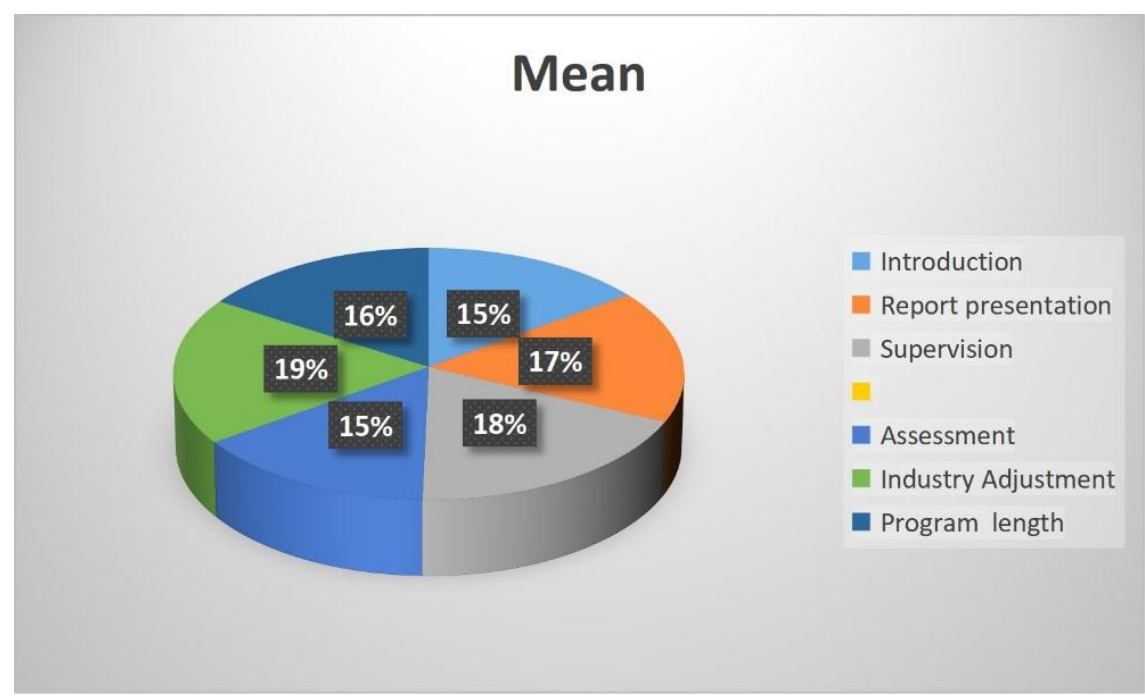

\section{ELEMENTS OF HANDLED PROGRAM}

Hypothesis 3: This factor plays the significant role in the Internship. Orientation, environment, planned program, assigned tasks, duties, hand -on- jobs, mentoring ,incentives, rewards and hiring opportunity are the elements in this factor.

The analysis is done by the point of view of the students and outsiders( includes employees, staff and other peoples.).The tabular and graphical presentation of the data is as follows: 
International Advanced Research Journal in Science, Engineering and Technology

Vol. 8, Issue 5, May 2021

DOI: $10.17148 / I A R J S E T .2021 .8585$

TABLE 4.3

\begin{tabular}{|l|c|c|c|}
\hline Elements & Outsiders & Students & Mean \\
\hline Orientation & 3 & 4 & 3.5 \\
\hline Environment & 3 & 5 & 4 \\
\hline Planned Program & 3 & 4 & 3.5 \\
\hline Assigned task and duties & 3 & 5 & 4 \\
\hline Mentoring & 3 & 4 & 3.5 \\
\hline Incentives, Rewards and Hiringopportunity & 3 & 5 & 4 \\
\hline
\end{tabular}

\section{Graph 1.7}
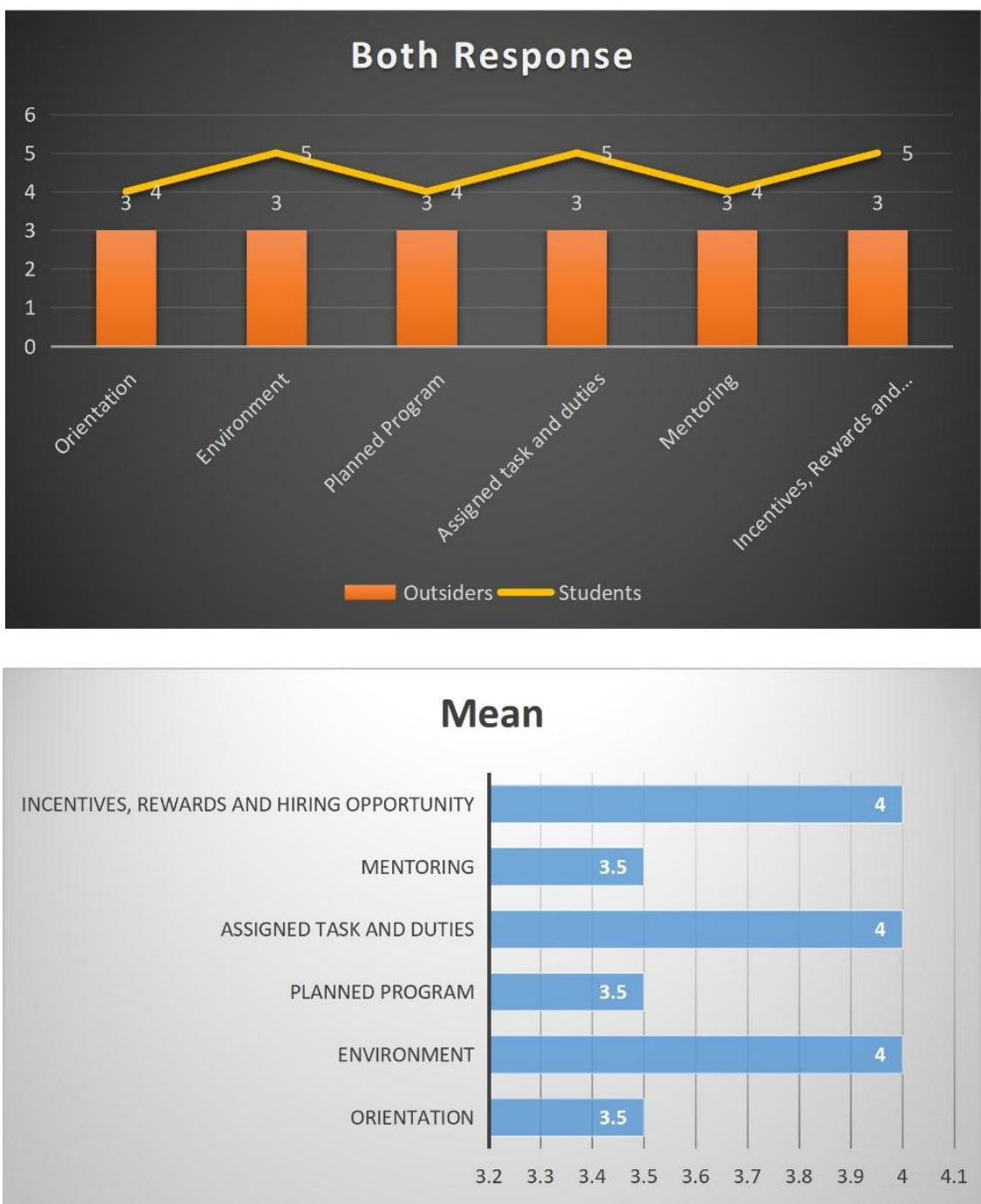

INTERPRETATION: The graph shows the mean response of the respondents. In this the incentives an hiring opportunity, assigned tasksand environment has same mean that is 4 and the mentoring, planned program, orientation has the same mean that is 3.5 .

\subsection{ELEMENTS OF INTERNSHIP FEEDBACK}

It is the subtitle of mentioned segments could be presented in any form toget the better result. Interns, Academy and Hotel HR are the elements in this factor.As feedback is the latest trend which is important in internshipwhich clearly shows the how the interns, academy and hotel are considered. It is the last factor that affect the Internship. Table 4.4. represents the responses. 
International Advanced Research Journal in Science, Engineering and Technology

Vol. 8, Issue 5, May 2021

DOI: $10.17148 /$ IARJSET.2021.8585

TABLE 4.4

\begin{tabular}{|l|c|c|c|}
\hline Elements & Outsiders & Students & Mean \\
\hline Intern & 4.07 & 4.10 & 4.085 \\
\hline Academy & 4.03 & 3.59 & 3.81 \\
\hline Hotel HR & 3.58 & 3.16 & 3.37 \\
\hline
\end{tabular}

\section{Graph 1.8}

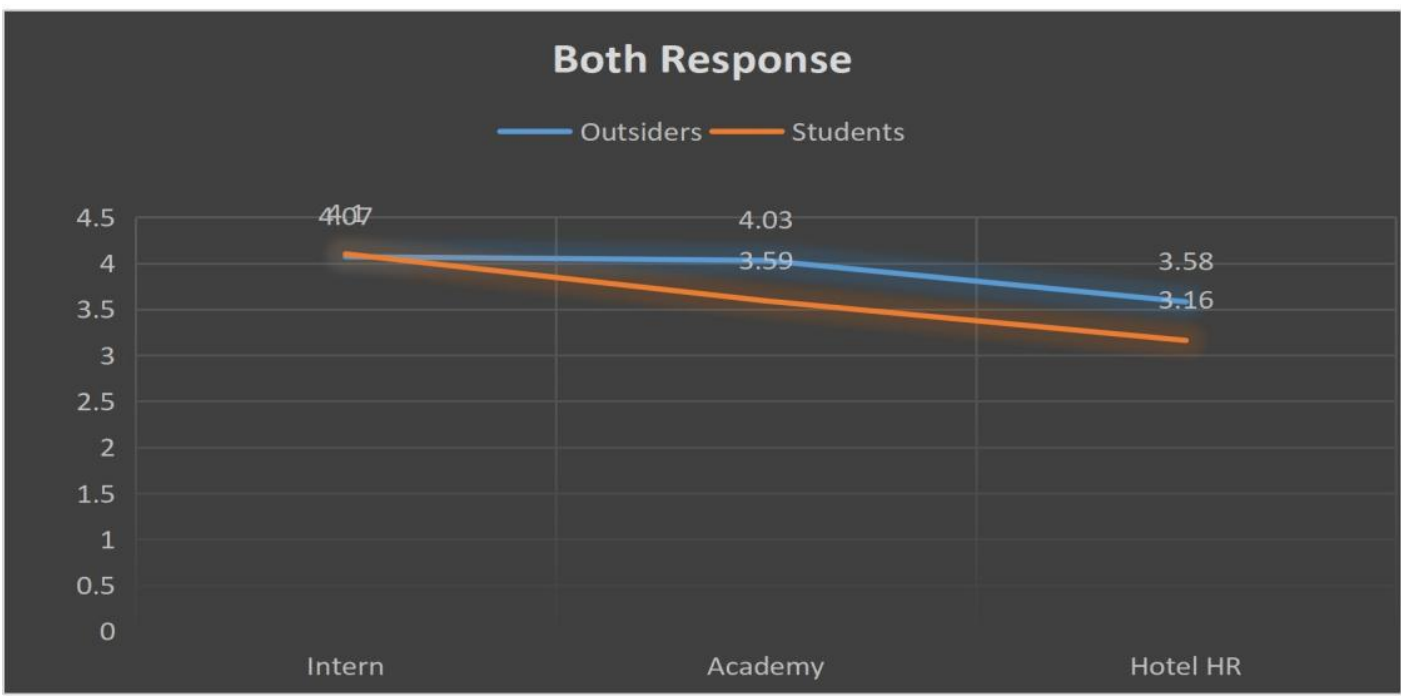

INTERPRETATION: In the graph the analysis is done reference of theboth the respondents. Te mean graph of the responses is shown in the graph 4.35

\section{Graph 1.9}

\section{Mean}

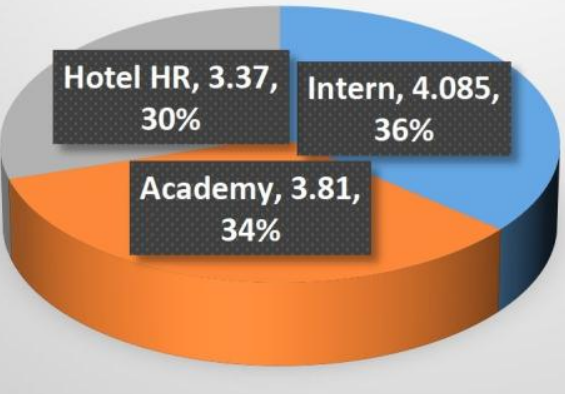

Intern

Academy

- Hotel HR

INTERPRETATION : Both group believe that feed back to intern has thehighest importance, when hotel practitioners think that feedbacks to academy is also important in internship program to be developed.

The answers of the people who have participated in this research as sample have resulted which related items have more effect on internship.Participants had different responses. The mean of elements involved in each factor can be used to assess the importance of each factor. 


\section{International Advanced Research Journal in Science, Engineering and Technology}

Vol. 8, Issue 5, May 2021

DOI: 10.17148/IARJSET.2021.8585

\section{CONCLUSION AND FINDINGS:}

Some of the findings of the research are:

Based on the demographic analysis it shows that the ideas by the outsiders have more influences on the overall results. Here by outsiders we mean the students who are not doing the internships but participated in the survey.

\section{FINDING BASED ON OBJECTIVES:}

OBJECTIVE 1: As it is shown the graphs above the interns believe in the expectation and the perception are most important elementsbecause when the students start with any internship perception and expectations affects more than other elements of the intern's quality.

OBJECTIVE 2: In the internship, the designed academic program plays the vital role in the internships. As in this introduction, and supervision are more effective than other elements of the designed academic program.

OBJECTIVE 3: By the results of the data analysis the students believe that the task and duties are more significant elements.

OBJECTIVE 4: Feedbacks are more important for the intern

\section{SUGGESTIONS AND RECOMMENDATIONS:}

The four main factors of internship were discussed and evaluated by the two groups of selected point of view. By presented literature some positive points are also can be the weaknesses for the priorities. Although as it mentioned before it is not a long time that hospitality education and hotel industry have been expanded in India. And this industry is not an experienced industry in our country but to improve internship programs and absolutely based on that hotel operation, some suggestions are mentioned to students, scholars and hotel practitioners.

All presented statistics, figures and tables in this research shows the quality of interns who are mostly students, attracted numerous people ideas compare to other existed elements of Internship program. Firstly itis suggested that all students who are going to work in hotel as an intern must be a person who likes people and practice to work as a team. They are going to deal with variety of people with different culture and attitudes. So they have to improve their communication, interpersonal, verbal, nonverbal and personal skills before and during their internship program for better relation with both customers and hotel staffs who are working with. It must be added mentioned skills are bold specially tohave the ability of presenting and explaining needed subject, politely, serious and warm to the guests. Students must be careful about details as it's not possible to learn all in classes like unpredictable cases and problems. Internship is a good opportunity for students to verify their knowledge with real work like something that happen every day in hotels and adjusting university courses according to hotel needs based on feedbacks.

\section{LIMITATIONS AND DELIMITATIONS OF THE STUDY:}

The results of the research could be changed if the number of respondent increases, so we suggest to other researchers to examine the results based on higher number of respondents.

- As it is mentioned, if the opinions of academics were not omitted, the result could be different. Thus for new research it would be better if the academics' ideas could be compared with other groups.

- The research could be a comparison between different countries, different hotel schools or universities.

- The elements of internship can be evaluated from each department of hotel separately, such as front office, housekeeping and etc.

- The elements of internship can be examined based on job positions.

- The priority of internship factors and elements of a well-developedcountry can be compared with a thirdworld country.

- A qualitative research can be conducted based on different datagathering methods and analyses, such as observation, interviews, and etc.

- At the bottom line draw interns' attention to an old saying which says:“ I hear and I forget, I see and I remember, I do and I understand" 


\section{International Advanced Research Journal in Science, Engineering and Technology}

Vol. 8, Issue 5, May 2021

DOI: $10.17148 /$ IARJSET.2021.8585

\section{REFERENCES}

[1]. Article on Rana's system, Available: www.ecs.com.np Accessed February17,2012.

[2]. Barrows C. \& Bosselman R. (1999)," Hospitality management education.Binghamton", NY: The Haworth Hospitality Press, p. 38.

[3]. Baum T. (2006). "Human resource management for tourism, hospitalityand leisure: An International perspective", London, England: Thomson Learning, pp. 201-204.

[4]. Beggs B. \& Ross C. M.\& Goodwin B. (2008),"A Comparison of Student and Practitioner: Perspectives of the Travel and Tourism Internship", Journal of Hospitality, Leisure, Sport and Tourism Education Vol.7, No.1,pp. $31-39$

[5]. Boud D., Garrick J. (1999), "Understandings learning at work", London,England, Routledge, pp. 1-6, 53-165

[6]. Cary Simmons J. (2006), "Hospitality internships as a career development tool: stakeholder perceptions and expectations", Doctoraldissertation, pp. $1-35$

[7]. Chess B., West B. (2007), "Secure Programming with Static Analysis",Boston: AddisonWesley.

[8]. Salant, P., \& Dillman D. A. (1994),"How to conduct your own survey”,New York, USA, John Wiley and Sons, pp. 13-53.

[9]. Sarmad Z., Bazargan A. \& Hejazi E. (2000) "Research Methodologies inBehavioral Sciences", 3rd edition, Tehran, Iran, Agah, pp. 79-95.

[10]. Satyal (1999), "Tourism in Nepal”, Nepal, Adroit Publishers, pp. 192-194

[11]. Schambac, T., Dirks, J. (2002), "Student perceptions of internship experiences", Proceedings of the 17 th annual conference of the international academy for information management, Statesboro, GA:Georgia Southern University. ED481733, pp. 1-8

[12]. Seyyedali Routeh Z. (2012), "Pathology of HRM in Iran: Hospitalityindustry case study", Master Thesis, pp. 30-75

[13]. Walk, M., \& Pike, N. (1989), "Guiding your internship”, EnglewoodCliffs, New Jersey: Prentice Hall, ix

[14]. Zopiatis A. (2007), "Hospitality internships in Cyprus: a genuine academic experience or a continuing frustration?” International Journalof Contemporary Hospitality Management, Vol.19, No. 1, pp. 65 